\title{
Coastal flooding, areas and depths, on a sand beach in the Mexican Caribbean under storm conditions
}

\section{Inundación costera, áreas y profundidades, en una playa de arena del Caribe mexicano bajo condiciones de tormenta}

\author{
CHÁVEZ-CÁRDENAS, Xavier*†, DELGADILLO-CALZADILLA, Miguel Ángel, GUTIERREZ- \\ VILLALOBOS, José M. and MORALEZ-GARIBAY, María Cristina
}

Universidad de Guanajuato Campus Celaya-Salvatierra, Av. Javier Barros Sierra 201 Col. Ejido de Santa María del Refugio C.P. 38140 Celaya, Gto. México

ID $1^{\text {st }}$ Author: Xavier, Chávez-Cárdenas / ORC ID: 0000-0001-6691-4380, Researcher ID Thomson: F-3210-2018, CVU CONACYT ID: 269911

ID $1^{\text {st }}$ Coauthor: Miguel Ángel, Delgadillo-Calzadilla / ORC ID: 0000-0003-3431-1942, Researcher ID Thomson: S-69192018, CVU CONACYT ID: 272236

ID $2^{\text {nd }}$ Coauthor: José M., Gutierrez-Villalobos / ORC ID: 0000-0001-5947-1489, Researcher ID Thomson: S-7666-2018, CVU CONACYT ID: 173461

ID $3^{\text {rd }}$ Coauthor: María Cristina, Moralez-Garibay / ORC ID: 0000-0003-4945-0582, CVU CONACYT ID: 560553

DOI: $10.35429 / \mathrm{EJRS} .2019 .8 .5 .1 .6$

Received February 14, 2019; Accepted June 28, 2019

Abstract

The objective of this study is to calculate the areas and depths of flooding that originate under storm conditions, in a pristine sand beach in the Mexican Caribbean. The calculation is done with the help of the XBeach numerical model. The simulated scenarios correspond to three storms that have occurred in the study zone, and the water wave conditions (significant wave height, propagation direction and period) of each storm were obtained from results of the WAVEWATCH III model. The topography and bathymetry used to generate the meshes have a resolution of 5 and 4 meters, respectively. Water level and sediment transport results were processed to obtain flood areas and depths. These data are very important because they contribute to establishing a flood risk zoning that serves as a guide to define the most appropriate area, design and construction processes and thus maintain balance in the coastal ecosystem avoiding beach loss and structural damage.

Coastal Flooding, Flood Depth, Storm
Resumen

El objetivo del presente estudio es calcular las áreas y profundidades de inundación, que se originan bajo condiciones de tormenta, en una playa virgen de arena en el Caribe Mexicano. El cálculo se realiza con ayuda del modelo numérico XBeach. Los escenarios simulados corresponden a tres tormentas que se han presentado en la zona de estudio, y las condiciones de oleaje (altura de ola significante, dirección de propagación y periodo) de cada tormenta se obtuvieron a partir de resultados del modelo WAVEWATCH III. La topografía y batimetría empleadas para la generación de las mallas tienen una resolución de 5 y 4 metros, respectivamente. Los resultados de nivel de agua y transporte de sedimento se procesaron para obtener las áreas y profundidades de inundación. Estos datos son muy importantes pues contribuyen a establecer una zonificación de riesgo por inundación que sirva de guía para definir la zona, diseño y procesos de construcción más adecuados y de esta manera mantener el equilibrio en el ecosistema costero evitando pérdida de playa y daño estructura.

Inundación costera, Profundidad de Inundación, Tormenta

Citation: CHÁVEZ-CÁRDENAS, Xavier, DELGADILLO-CALZADILLA, Miguel Ángel, GUTIERREZ-VILLALOBOS, José M. y MORALEZ-GARIBAY, María Cristina. Coastal flooding, areas and depths, on a sand beach in the Mexican Caribbean under storm conditions. ECORFAN Journal-Republic of El Salvador. 2019. 5-8: 1-6.

\footnotetext{
* Correspondence to Author (email: x.chavez@ugto.mx)

$\dagger$ Researcher contributing first author.
} 


\section{Introduction}

Undoubtedly, of the effects caused by storms, coastal flooding is one of the most worrisome from the point of view of security and economy. For this reason, the various studies carried out mainly focus on areas with urban development, mainly of a tourist nature.

The issue of coastal erosion is of great importance due to its direct relationship with the flood (loss of beach). Within the Caribbean area, Juanes (2019) mentions various experiences and measures with which Cuba faces coastal erosion, among which the elevation of the sea level as a cause of erosion, which is manifested in terms of flooding.

Another issue with special relevance is ecosystem resilience, and tourism resilience is even addressed in the event of hurricanes. (Infante et at., 2019).

Most of the mentioned studies rely on numerical models as a tool to carry out prediction studies, which at the same time allow the design of engineering solutions based on shelter structures. This approach facilitates the analysis of various scenarios or storm conditions in combination with different positions, shapes and dimensions of the protection structures. Among the most used models are XBEACH, DELFT3D, TELEMAC, WAPO. SICOM With the latter, a study of hydrodynamics and morphodynamics was carried out on the north coast of Cuba. (González y Córdova, 2019).

The interest of dimensioning the danger due to flooding lies in places of low or immediate elevation to the beach, in ecosystems that have limited resilience to the occurrence of natural phenomena and in places where in addition to having the aforementioned characteristics there are locations with a high demographic index. (Neumman et al 2015)

This paper deals with coastal flooding under storm conditions, but from a preventive perspective. A sandy beach, virgin and with potential for tourism development, is evaluated under storm conditions to identify the flood surface and depths. These parameters are determined with the help of the XBEACH numerical model and the use of telescopic meshes to increase efficiency, improve accuracy and decrease computation time.
Flood areas and their depths are essential to establish adequate planning in the development and construction of infrastructure, through specific recommendations in terms of safe areas (without risk of flooding) and / or adequate construction techniques, on land with flood risk, which guarantee the structural safety of the works and respect the natural balance of the ecosystem.

The research is presented under the following scheme. The Study Zone section describes the location, selection criteria and characteristics of the chosen sandy beach. The numerical model used and its input parameters are presented in the XBEACH name section. The simulated scenarios are reflected in the Simulations part, while the results and their corresponding analysis are included in the Results and Analysis section. Finally, Conclusions summarizes the most relevant results and defines the opportunities for better.

\section{Study zone}

A sandy beach located in the Riviera Maya region was selected for two reasons. The region is one of the main tourist destinations worldwide and its impact has a significant impact on the economy of the country and the low elevations of the topography of the area, make it vulnerable and susceptible to flooding.

The beach is located at the UTM (Universal Transverse Mercator) coordinates $468517 \mathrm{~m} \mathrm{E}$ and $2257400 \mathrm{~m} \mathrm{~N}$ (see Figure 1). It is a bay whose main morphological characteristics are a mouth width of $550 \mathrm{~m}$ and $250 \mathrm{~m}$ in length between the mouth and the coast.

The relief of the region is classified as flat and near the beach it has a primary dune that does not exceed 5 meters above sea level.

It is a beach or bar of rocky or cemented floor. The predominant rock is limestone sedimentary, while the soil is leptosol.

It is a region hit by storms during the months of July to December. 


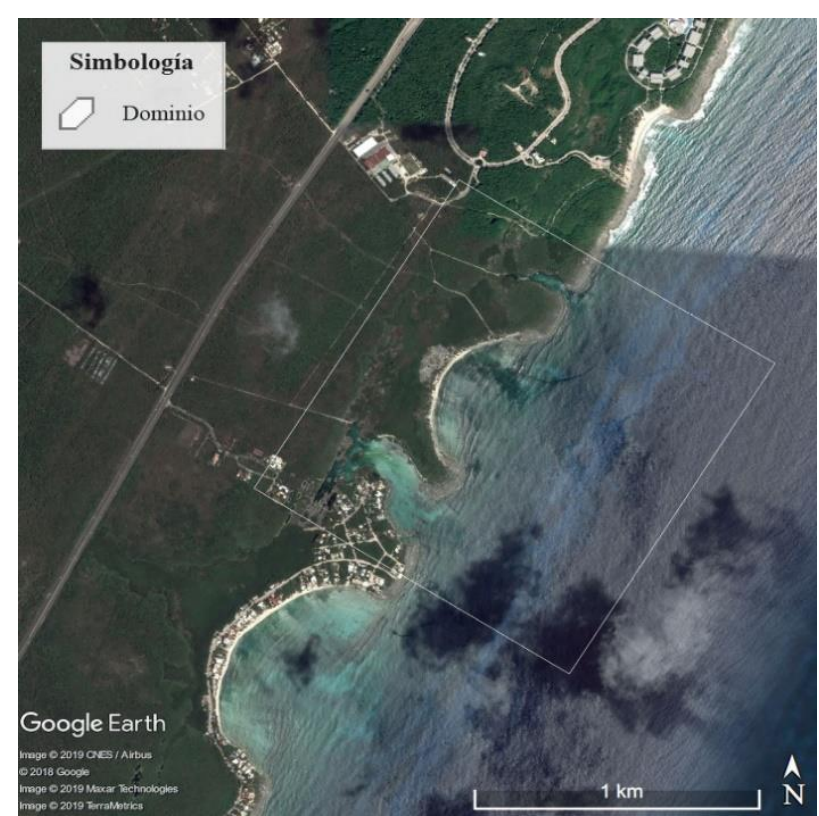

Figure 1 Study area

Source: Google Earth

\section{XBEACH}

XBeach is a two-dimensional model for the propagation of waves, long waves and medium flow, sediment transport and morphological changes of the area near the coast, beaches, dunes and containment barrier during storms. The main input parameters used to feed the model are described in the following sections.

\section{Domain}

The domain was delimited based on the definition of littoral cell (Inman, 2003). The coves were included on the sides of the bay, because they confine the sediment within the domain and perpendicular to the coast the elevation was taken into consideration; at sea, a suitable depth to enter the waves (16 $\mathrm{m}$ ), and on land, the highest elevations of the land $(3 \mathrm{~m})$. The area of land within the domain is $616,500.0$ $\mathrm{m}^{2}$.

Under the aforementioned considerations, the domain was set with a length, parallel to the coast, of $1350 \mathrm{~m}$ and perpendicular to the coast of $1240 \mathrm{~m}, 280 \mathrm{~m}$ inland and $960 \mathrm{~m}$ to deep water (see Figure 2).

To cover the domain, a telescopic mesh was generated, which includes a maximum resolution area with a cell size of $2 \mathrm{~m}$ in both directions.

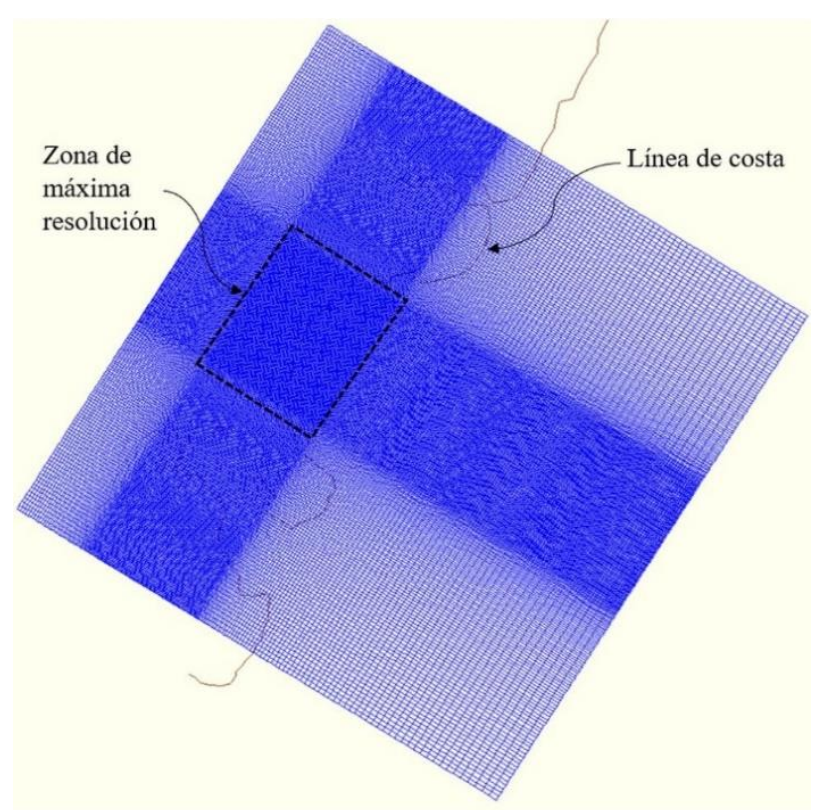

Figure 2 Computational domain

\section{Background Border}

The background boundary was established with the combined topography and bathymetry information and entered as values in the nodes of the created mesh.

The topographic data were obtained from the INEGI (National Institute of Statistics and Geography) and correspond to a digital model of high resolution elevations, LiDAR (Detection and Measurement through light) the spatial resolution of the data is $5 \times 5 \mathrm{~m}$.

The bathymetry data were obtained from CONABIO (National Commission for the knowledge and use of Biodiversity) with a spatial resolution of $4 \times 4 \mathrm{~m}$, and for the deep waters the global land surface model ETOPO was used.

The combination of the information allowed to generate the background relief of the domain (Figure 3). 


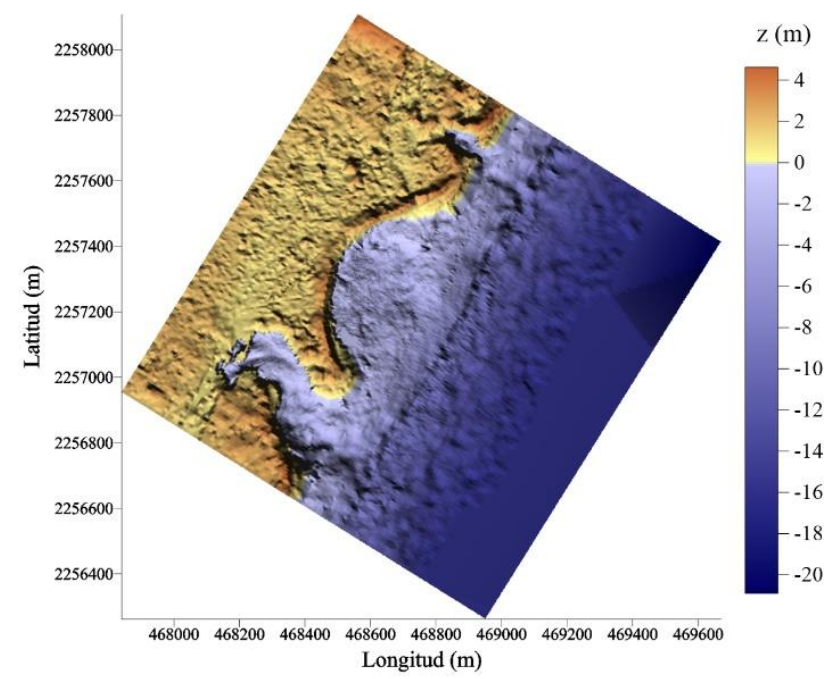

Figure 3 Topo-bathymetry of the domain

\section{Surf}

The waves in the area were obtained from the WAVEWATCH III (WWIII) registry, from 2005 to date. The WWIII cell considered is 9.5 $\mathrm{km}$ south of the study area. The log time interval is 3 hours.

To locate the storms within the WWIII registry, the historical trajectories of hurricanes of the NOAA (National Oceanic and Atmospheric Administration) were consulted. Within a radius of $100 \mathrm{~km}$ from the study area, between 2005 and 2007, there are 3 tropical storms (Stan 2005, Dolly 2008 and Rina 2011), a tropical depression (Olga 2007) and two hurricanes class 4 ( Emily 2005 and Wilma 2005). The data required by the numerical model are: Significant wave height, $\mathrm{Hs}(\mathrm{m})$, period, $\mathrm{T}$ (s) and direction of propagation, $\mathrm{D}\left({ }^{\circ}\right)$. The Nautical convention, North $0^{\circ}$, East $90^{\circ}$, South $180^{\circ}$ and West $270^{\circ}$ were managed for the direction.

\section{Sediment}

The sediment properties were obtained from records close to the study area, these records and their corresponding statistical analysis were carried out by Ruiz-Martínez et al. (2013)

Based on the satellite images, the sediment banks susceptible to being transported were determined.

\section{Simulations}

Three storm scenarios were selected and the data were taken from the maximum condition of tropical depression (Olga 2007) and hurricanes Emily (2005) and Wilma (2005).

The simulation time for the three cases was 24 hours, this is equal to 8 wave conditions taken from the WWIII cell register. Because the frequency of recording the wave data is 3 hours, the simulation time of each condition is 10800 seconds. The wave conditions for the simulations of the three scenarios are shown in Tables 1, 2 and 3.

\begin{tabular}{|r|r|r|}
\hline Hs (m) & \multicolumn{1}{|c|}{$\mathbf{T}(\mathbf{s})$} & $\mathbf{D}\left(^{\circ}\right)$ \\
\hline 0.55 & 4.50 & 125.5 \\
\hline 0.98 & 6.46 & 108.17 \\
\hline 1.26 & 7.16 & 108.82 \\
\hline 1.36 & 7.81 & 109.88 \\
\hline 1.39 & 8.32 & 112.43 \\
\hline $\mathbf{1 . 4 3}$ & $\mathbf{8 . 4 5}$ & $\mathbf{1 1 2 . 3 6}$ \\
\hline 1.40 & 8.28 & 111.97 \\
\hline 1.35 & 8.31 & 111.26 \\
\hline
\end{tabular}

Table 1 Wave conditions of scenario 1 Olga, 2007

\begin{tabular}{|r|r|r|}
\hline Hs (m) & \multicolumn{1}{|c|}{$\mathbf{T}(\mathbf{s})$} & $\mathbf{D}\left(^{\circ}\right)$ \\
\hline 0.95 & 12.24 & 109.46 \\
\hline 1.75 & 12.08 & 107.13 \\
\hline $\mathbf{3 . 0 4}$ & $\mathbf{1 1 . 8 9}$ & $\mathbf{1 0 2 . 3 9}$ \\
\hline 2.36 & 10.9 & 101.31 \\
\hline 1.87 & 10.54 & 100.48 \\
\hline 1.56 & 9.9 & 102.69 \\
\hline 1.4 & 9.4 & 103.36 \\
\hline 1.35 & 9.01 & 105.49 \\
\hline
\end{tabular}

Table 2 Wave conditions of scenario 2, Emily 2005

\begin{tabular}{|r|r|r|}
\hline \multicolumn{1}{|c|}{ Hs (m) } & \multicolumn{1}{c|}{$\mathbf{D}\left({ }^{\circ}\right)$} \\
\hline 3.46 & 13.38 & 110.31 \\
\hline $\mathbf{3 . 6 5}$ & $\mathbf{1 3 . 1 8}$ & $\mathbf{1 1 1 . 3 8}$ \\
\hline 3.29 & 12.71 & 110.77 \\
\hline 3.47 & 12.62 & 111.34 \\
\hline 3.34 & 12.4 & 110.84 \\
\hline 3.27 & 12.36 & 110.1 \\
\hline 3.36 & 12.31 & 107.86 \\
\hline 3.64 & 12.27 & 104.08 \\
\hline
\end{tabular}

Table 3 Wave conditions of scenario 3, Wilma 2005

\section{Results and Analysis}

Figure 4 shows the map of the water level directly calculated by the XBEACH. 


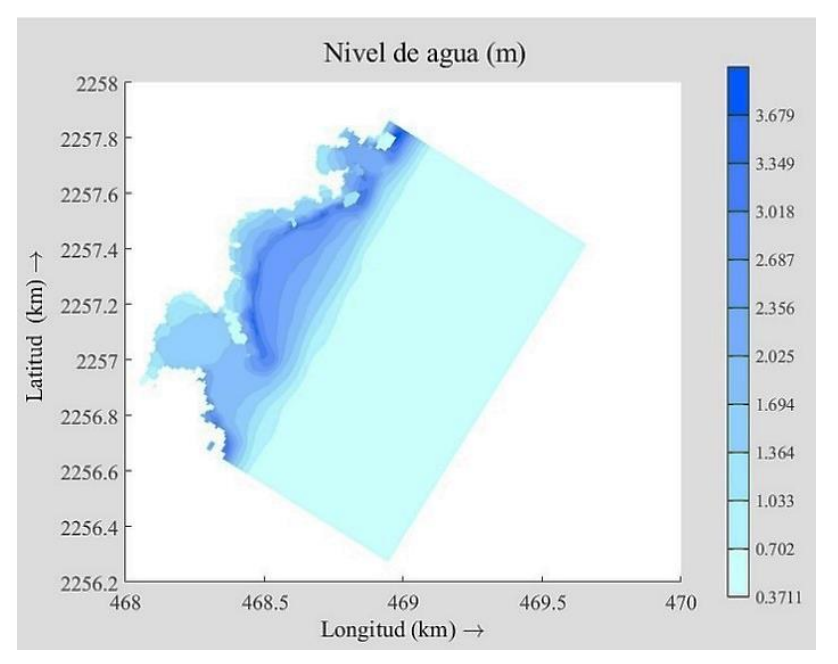

Figure 4 Wilma 2005 water level map, first wave condition

The map in Figure 4 shows that the water reaches levels above $3.5 \mathrm{~m}$. However, it is necessary to make the difference between the water level and the topography level to accurately determine the flood areas and the depths present in them. Figures 5, 6 and 7 show the flood areas and their depths. These results correspond to the condition of maximum significant wave height in each scenario.

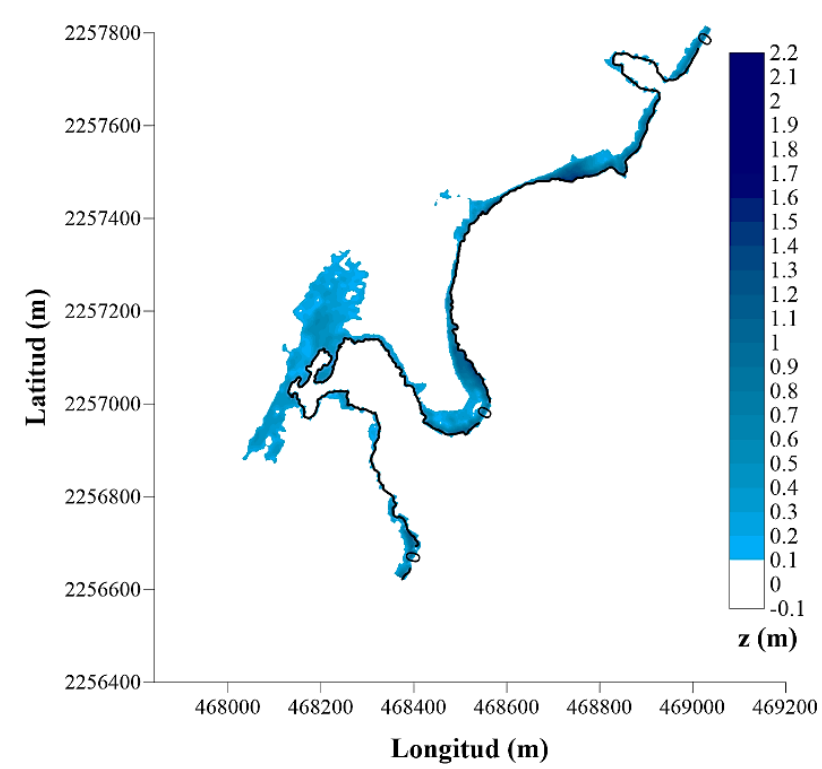

Figure 5 Map of flooding and depths, Olga 2007, Hs = $1.43 \mathrm{~m}$

The southern cove is the most vulnerable to flooding, while, for the bay beach, the flood initially occurs in the central part and the extremes.

It is clear in the three maps that the maximum depths are located between the coastline and the primary dune.

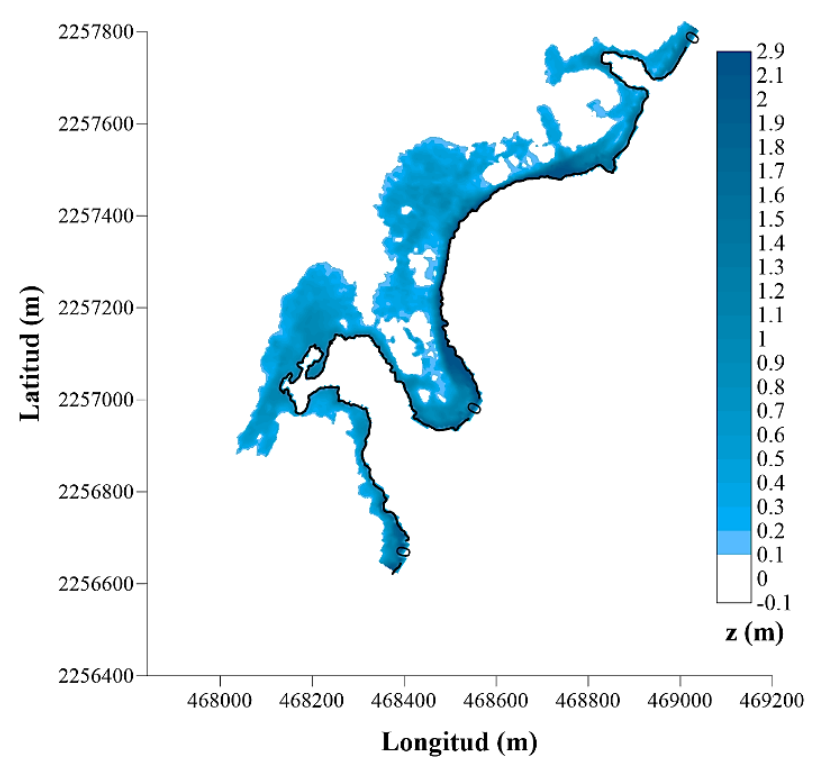

Figure 6 Map of flooding and depths, Emily 2005, Hs = $3.04 \mathrm{~m}$

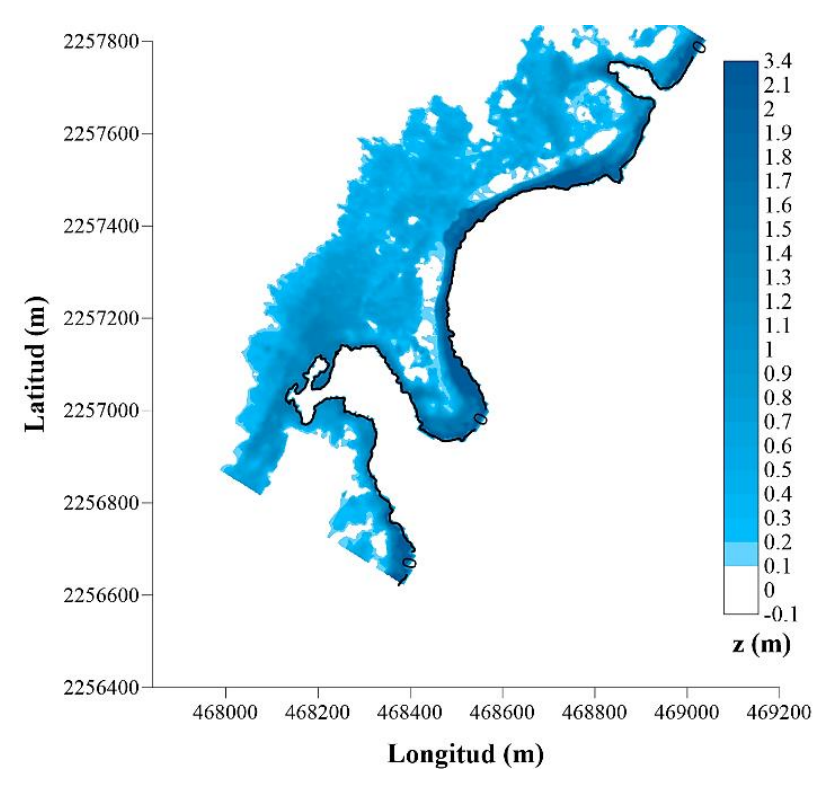

Figure 7 Map of flooding and depths, Wilma 2005, Hs = $3.65 \mathrm{~m}$.

Table 4 summarizes the maximum areas and depths for each case in its maximum wave condition.

\begin{tabular}{|l|r|r|}
\hline \multicolumn{1}{|c|}{ Stage } & \multicolumn{1}{c|}{ Area $\mathbf{( m}^{\mathbf{2}} \mathbf{r}$} & Depth (m) \\
\hline Olga 2007 & 79600 & 2.2 \\
\hline Emily 2005 & 210300 & 2.9 \\
\hline Wilma 2005 & 380000 & 3.4 \\
\hline
\end{tabular}

Table 4 Maximum areas and depths per scenario.

\section{Conclusions}

The comparison of flood maps clearly shows the difference between a tropical depression and a hurricane. The flood area of Olga 2007, Emily 2005 and Wilma 2005 represents 13\%, 34\% and $62 \%$ of the total land area, respectively. 
The results may be better if you perform a more detailed analysis, obtaining the areas for different depths. An analysis should also be carried out at the end of the storms, but it is recommended to increase the inland domain because in the case of Wilma it is appreciated that the flood reached the border of the domain.

\section{Acknowledgments}

The research project was funded by the Program for Professional Teacher Development, PRODEP, through the Support for the Incorporation of NPTC, project with folio UGTO-PTC-637.

\section{References}

González Valdés, P., \& Córdova López, L. F. (2019). Aplicación del sistema computacional SICOM en la costa norte de Cuba. Ingeniería Hidráulica y Ambiental, 40(2), 50-64.

Infante, M. A. H., Solís, V. V., \& Aponte, Á. G. P. (2019). Expresión territorial de la resiliencia turística ante la ocurrencia de eventos hidrometeorológicos en Los Cabos-Baja California Sur, México. Estudios y perspectivas en turismo, 28(2), 486-506

Inman, D. L. (2003). Littoral Cells. Reprint from Encyclopedia of Coastal Science (M. Schwartz, editor.

Martí, J. L. J. (2019). Experiencias cubanas en el enfrentamiento a la erosión costera. Revista Comunicaciones Científicas y Técnológicas, 4(1), 317-321

Neumann, B., Vafeidis A. T., Zimmermann J., Nicholls, R. J. (2015). Future coastal population growth and exposure to sea-level rise and coastal flooding-a global assessment. PloS one, 10(3), e0118571.

Ruiz-Martínez, G., Silva-Casarín, R., PosadaVanegas, G. (2013). Comparación morfodinámica de la costa noroeste del estado de Quintana Roo, México. Tecnología y ciencias del agua, 4(3), 47-65 